\title{
PENGARUH PRESTASI BELAJAR, DUKUNGAN SOSIAL KELUARGA DAN TEMAN SEBAYA TERHADAP LITERASI KEUANGAN SISWA
}

\author{
Dian Sukmawati, Pascasarjana Universitas Negeri Surabaya \\ diansukmawati50@gmail.com
}

\begin{abstract}
ABSTRAK
Penelitian ini bertujuan untuk menganalisis pengaruh prestasi belajar Ekonomi, dukungan sosial keluarga dan teman sebaya secara parsial maupun simultan terhadap literasi keuangan siswa kelas XII di SMA Negeri di Kabupaten Dompu. Populasi dalam penelitian adalah siswa kelas XII di SMA Negeri di Kabupaten Dompu. Penelitian ini menggunakan teknik proporsional area probability sampling dengan menggunakan teknik analisis regresi. Hasil penelitian menunjukkan bahwa: 1) Prestasi belajar mata pelajaran Ekonomi berpengaruh positif terhadap literasi keuangan siswa, 2) Dukungan sosial keluarga berpengaruh positif terhadap literasi keuangan siswa, 3) Dukungan sosial teman sebaya pengaruh positif terhadap literasi keuangan siswa dan 4) Prestasi belajar, dukungan sosial keluarga dan teman sebaya secara simultan pengaruh terhadap literasi keuangan siswa SMA Negeri di Kabupaten Dompu. Sehingga dapat dikatakan bahwa ketiga variabel tersebut merupakan faktor-faktor yang mempengaruhi literasi keuangan siswa SMA Negeri di Kabupaten Dompu.

Kata kunci: prestasi belajar, dukungan sosial keluarga, dukungan sosial teman sebaya, literasi keuangan.
\end{abstract}

\begin{abstract}
This study aims to analyzing the influence of the learning achievement of economics, family social support and peer simultaneously and partial toward financial literacy student in public senior high school in Dompu. This research is associative causal research with a quantitative approach. The population is students of $12^{\text {th }}$ grade in public senior high school in Dompu. This study used proporsional area probability sampling with regression analysis techniques. The results showed that the learning achievement, social support of family and peers significantly affect the financial literacy of high school students of State in Dompu. The conclusion are 1) Economics achievement study has positive effect on the financial literacy of students, 2) Families Social support positive effect on the financial literacy of students, 3) peer social support positive influence on the financial literacy of students and 4) learning achievement, family support and peer simultaneously influence on the financial literacy of students of SMA in Dompu so that it can be said that these three variables are all factors that affect the financial literacy of high school students of State in Dompu.
\end{abstract}

Keywords: Learning achievement, family social support, peer social support, financial literacy 


\section{PENDAHULUAN}

Berdasarkan hasil observasi, diperoleh informasi bahwa pada umumnya sumber keuangan remaja di Kabupaten Dompu, Provinsi Nusa Tenggara Barat adalah uang saku dari orang tuanya yang diberikan secara harian atau mingguan sebesar Rp. 10.000 - Rp. 20.000 per hari, atau Rp. 75.000 - Rp. 100.000 per minggu. Pengalokasian uang saku tersebut untuk beberapa pengeluaran seperti membeli makanan dan minuman pada saat sekolah, biaya foto copy bahan pelajaran, membeli pulsa dan beberapa pengeluaran rutin lainnya baik ketika mereka sekolah di pagi sampai siang hari dan dilanjutkan mengikuti les atau kursus di sore hari. Namun tidak jarang mereka membutuhkan uang saku yang lebih dari yang sudah mereka terima dari orang tua, disebabkan pengeluaran mereka yang melebihi dari pengeluaran rutin yang semestinya. Beberapa penyebabnya adalah gencarnya iklan dan pengaruh pergaulan dengan teman sebaya.

Remund (2010) menyebutkan empat hal penting dalam literasi keuangan yaitu penganggaran (budgeting), tabungan (saving), pinjaman (borrowing) dan investasi (investing). Sementara Capuano \& Ramsay (2011) mengemukakan enam kompetensi inti literasi keuangan, yaitu: kemampuan dasar seseorang dalam pengelolaan keuangan (money basic), pengalokasian pemasukan dan pengeluaran (budgeting), menabung dan merencanakan, pengetahuan tentang pinjaman (borrowing) dan pemahaman dalam pengelolaan hutang (debt literacy), memahami produk-produk keuangan dan investasi serta kemampuan siswa untuk melindungi dirinya sendiri dari resiko keuangan. Komponen-komponen tersebut telah terkandung dalam kompetensi-kompetensi dasar yang harus dikuasai siswa dalam mata pelajaran Ekonomi, khususnya siswa yang memilih program studi Ilmu Pengetahuan Sosial (IPS). Penguasaan siswa tentang kompetensi-kompetensi dasar tersebut melalui serangkaian proses dan tugas yang harus diselesaikan ditunjukkan oleh prestasi belajar mereka dalam bentuk nilai.

Berdasarkan kajian empiris, ditemukan bahwa mahasiswa program studi ekonomi yang memperoleh beberapa mata kuliah terkait pengelolaan atau manajemen keuangan memiliki tingkat literasi keuangan yang lebih tinggi daripada mahasiswa non ekonomi (Krishna dkk, 2010). Gutter et al. (2008) menyimpulkan bahwa baik pembelajaran sosial dan pendidikan formal merupakan penentu penting dari perilaku keuangan seseorang yang merupakan bagian dari literasi keuangan. Berdasarkan hasil-hasil penelitian tersebut dapat disimpulkan bahwa dengan mempelajari ekonomi maka akan membentuk pengetahuan seseorang tentang pengelolaan keuangan sebagai bagian dari yaitu literasi keuangan menjadi lebih baik, yang selanjutnya akan nampak pada perilaku keuangan seseorang.

Penelitian yang dilakukan oleh Safree dan Adawiyah (2011) menemukan bahwa siswa dengan dukungan sosial yang baik, memiliki keluarga yang harmonis dan teman-teman yang baik akan meraih prestasi akademis yang baik pula. Penyebabnya adalah meningkatkan persepsi dan kepercayaan diri siswa yang bersumber dari nasihat dan dorongan positif sehingga mereka sehat secara psikologis. Penelitian Mashlihah (2011) menemukan bahwa dukungan sosial berupa pengakuan akan kemampuan dan kualitas diri sangat menyentuh kebutuhan emosional sehingga siswa merasa dihargai dan dikasihi. Terdapat 
hubungan yang signifikan antara prestasi akademik siswa yang mendapatkan dukungan sosial dari orang tua berupa instrumental support, yaitu kesiapan orang tua untuk memberikan bantuan, bimbingan dan nasihat saat dibutuhkan anak, dengan prestasi akademis. Hal ini sangat bermakna bagi anak sehingga menjadi energi positif untuk berprestasi.

Dalam hubungannya dengan literasi keuangan, penelitian Susanti (2013) menemukan hasil bahwa selain pembelajaran keuangan di perguruan tinggi, pembelajaran keuangan di keluarga dan pengaruh interaksi teman sebaya merupakan faktor-faktor yang mempengaruhi literasi keuangan mahasiswa Fakultas Ekonomi Universitas Negeri Surabaya. Penelitian Cude et al. (2007) menyimpulkan bahwa orang tua memegang peranan penting dalam proses sosialisasi keuangan kepada anak-anaknya. Hal senada juga ditemukan dalam penelitian Jorgensen (2010) bahwa mahasiswa yang belajar tentang pengelolaan keuangan pada orang tuanya memiliki pengetahuan keuangan yang lebih tinggi daripada yang tidak belajar pengelolaan keuangan dari orang tuanya. Berdasarkan hasil-hasil penelitian tersebut, dapat disimpulkan bahwa dukungan sosial yang bersumber dari keluarga yaitu orang tua sangatlah dibutuhkan dan penting bagi proses belajar anak termasuk dalam mencapai literasi keuangan.

Penelitian Azizi (2013) menemukan bahwa tidak hanya dukungan sosial keluarga yang berpengaruh terhadap indeks prestasi komulatif (grade point average/GPA) siswa, namun dukungan sosial teman sebaya juga berpengaruh khususnya bagi siswa laki-laki. Dalam penelitian Susanti (2013) juga menemukan hasil bahwa interaksi teman sebaya merupakan salah satu faktor yang mempengaruhi literasi keuangan mahasiswa Fakultas Ekonomi Universitas Negeri Surabaya.

Berdasarkan penelitian-penelitian tersebut, maka dapat disimpulkan bahwa dalam proses belajar tidak hanya mengandalkan sekolah karena dibutuhkan peran serta berupa dukungan dari keluarga yaitu orang tua dan teman sebaya sebagai pihak-pihak yang dapat diandalkan oleh siswa. Proses ini juga termasuk pada penanaman literasi keuangan yang secara kognitif telah dipelajari di sekolah. Secara penerapan berupa pembiasaan dan contoh teladan didapatkan anak dari keluarganya yaitu orang tua. Demikian pula pada siswa-siswi SMA di Kabupaten Dompu yang dalam proses belajarnya juga membutuhkan keterlibatan langsung dari para orang tua dan teman-temannya berupa perhatian, nasihat, kasih sayang, dan contoh tauladan.

Capuano \& Ramsay (2011) mendefinisikan literasi keuangan adalah pengetahuan dan pemahaman tentang konsep-konsep keuangan sehingga menghasilkan kemampuan untuk membuat keputusan yang efektif tentang uang. Remund (2010) menjelaskan bahwa dasar dari literasi keuangan adalah kemampuan seseorang dalam mengelola uang. Berdasarkan beberapa riset tentang literasi keuangan sejak tahun 2000, Remund (2010) mengkategorikan definisi literasi keuangan dalam lima kategori, yaitu: 1) Pengetahuan tentang konsep keuangan, 2) Kemampuan untuk mengkomunikasikan konsep keuangan, 3) Kecerdasan dalam mengelola keuangan personal, 4) Keahlian dalam membuat keputusan keuangan yang tepat dan 5) Kepercayaan dalam merecanakan keuangan secara efektif untuk kebutuhan di masa yang akan datang.

Mason \& Wilson (dalam Cude et al., 2006) mendefinisikan literasi keuangan sebagai suatu proses penyusunan pemahaman di mana sesorang 
menggunakan kombinasi keahlian, sumber daya dan pengetahuan untuk memproses suatu informasi dan membuat keputusan berdasarkan pengetahuan keuangan. Cude et al. (2006) juga berpendapat bahwa perkembangan instrumen keuangan yang tidak diiringi dengan keinginan masyarakat untuk berinvestasi salah satu penyebabnya adalah rendahnya literasi keuangan. Pada penelitian ini menggunakan enam kompetensi inti yang dikemukakan oleh Capuano \& Ramsay (2011) sebagai indikator pengukuran literasi keuangan pada siswa kelas XII Program Studi IPS SMA Negeri di Kabupaten Dompu, yaitu: 1) Kemampuan dasar dalam pengelolaan keuangan (money basic), 2) Mengalokasikan pemasukan dan pengeluaran (budgeting), 3) Menabung dan merencanakan, 4) Pengetahuan tentang pinjaman (borrowing) dan pemahaman dalam pengelolaan hutang (debt literacy), 5) Memahami produk-produk keuangan dan investasi serta 6) Kemampuan seseorang untuk melindungi dirinya sendiri dari resiko keuangan dengan memahami prosedur penyelesaian masalah keuangan. Hal ini didasarkan pada asumsi bahwa siswa kelas XII Program Studi IPS SMA Negeri di Kabupaten Dompu telah mempelajari dan menguasai seluruh kompetensi dasar Ekonomi dan Akuntansi yang mereka pelajari sejak kelas X.

Tu'u (2004) berpendapat bahwa prestasi belajar adalah hasil dari penguasaan pengetahuan atau keterampilan setelah mengerjakan tugas atau kegiatan tertentu yang dikembangkan oleh mata pelajaran. Syah (2008) mendefinisikan prestasi belajar sebagai hasil yang dicapai siswa setelah melakukan interaksi dengan faktor-faktor yang mempengaruhi proses belajar. Djamarah (2002) mengemukakan bahwa prestasi belajar adalah perubahan dalam diri individu sebagai hasil dari aktivitas dalam suatu proses kegiatan belajar. Dalam penelitian ini, diasumsikan bahwa proses belajar telah dilalui siswa kelas XII dan evaluasi serta penilaian telah dilakukan oleh guru mata pelajaran Ekonomi yang mengajar di masing-masing sekolah. Prestasi belajar siswa ditunjukkan dalam bentuk nilai ujian akhir semester (UAS) genap tahun ajaran 2014-2015 yang mencakup ketiga ranah, yaitu kognitif, afektif dan psikomotor. Peneliti menggunakan nilai siswa pada ranah kognitif sebagai variabel yang mempengaruhi literasi keuangan.

Albrecht dan Adelman (dalam Mattson, 2011) mendefinisikan dukungan sosial sebagai suatu bentuk komunikasi baik secara verbal maupun nonverbal yang dapat mengurangi ketidakpastian situasi yang sedang dihadapi seseorang, kondisi dirinya sendiri, orang lain, atau hubungan dan fungsi di antara keduanya untuk meningkatkan persepsi kontrol pribadi dalam hidup seseorang sehingga orang tersebut merasa lebih nyaman. Menurut Caplan (dalam Littlewood et al., 2012) mendefinisikan dukungan sosial sebagai suatu hubungan formal dan informal antara individu dengan kelompok, di mana orang tersebut menerima dukungan emosional, kognitif dan materi untuk menghadapi kondisi stress.

Sumber dukungan sosial (Fezer, 2008) berasal dari lingkungan keluarga sebagai lingkungan terdekat remaja, yaitu orang tua dan dari sekolah seperti guru, teman sekelas dan teman sebaya sebagai lingkungan kedua bagi mereka. Penelitian ini menggunakan variabel dukungan sosial keluarga dengan memfokuskan pada dukungan orang tua dan teman sebaya. Hal ini didasarkan pada Teori Ekologis yang dikemukakan oleh Bronfenbrenner (dalam Santrock, 2003) yang menyatakan bahwa dalam perkembangannya, seorang anak berinteraksi dengan lingkungannya, salah satunya adalah mikrosistem yaitu 
lingkungan di mana mereka tinggal, dalam hal ini mencakup orang tua dan teman sebayanya. Dalam penelitian ini menggunakan lima jenis dukungan sosial menurut Schaefer et al. (dalam Mattson, 2011) sebagai indikator dukungan keluarga dan teman sebaya kepada remaja dalam memahami literasi keuangan, yaitu: emotional (emosional), esteem (penghargaan), network (jaringan), information (informasi), tangible (bantuan nyata). Konsep dukungan sosial tersebut lebih terperinci dan mencakup semua konsep yang dikemukakan Weiss (dalam Cutrona et al., 1994) maupun Cohen dan Syme (dalam Cheng et al., 2008) sehingga lebih dapat dioperasionalkan pada subyek penelitian yaitu siswa kelas XII SMA Negeri di Kabupaten Dompu.

Penelitian ini bertujuan untuk: 1) Menganalisis pengaruh prestasi belajar Ekonomi terhadap literasi keuangan siswa kelas XII di SMA Negeri di Kabupaten Dompu, 2) Menganalisis pengaruh dukungan sosial keluarga terhadap literasi keuangan siswa kelas XII di SMA Negeri di Kabupaten Dompu, 3) Menganalisis pengaruh dukungan sosial teman sebaya terhadap literasi keuangan siswa kelas XII di SMA Negeri di Kabupaten Dompu, dan 4) Menganalisis pengaruh prestasi belajar Ekonomi, dukungan sosial keluarga dan teman sebaya secara simultan terhadap literasi keuangan siswa kelas XII di SMA Negeri di Kabupaten Dompu.

\section{METODE PENELITIAN}

Penelitian ini berjenis penelitian asosiatif dengan hubungan kausal yang menggunakan pendekatan kuantitatif. Kerangka berpikir dalam penelitian ini ditunjukkan dalam bagan di bawah ini:

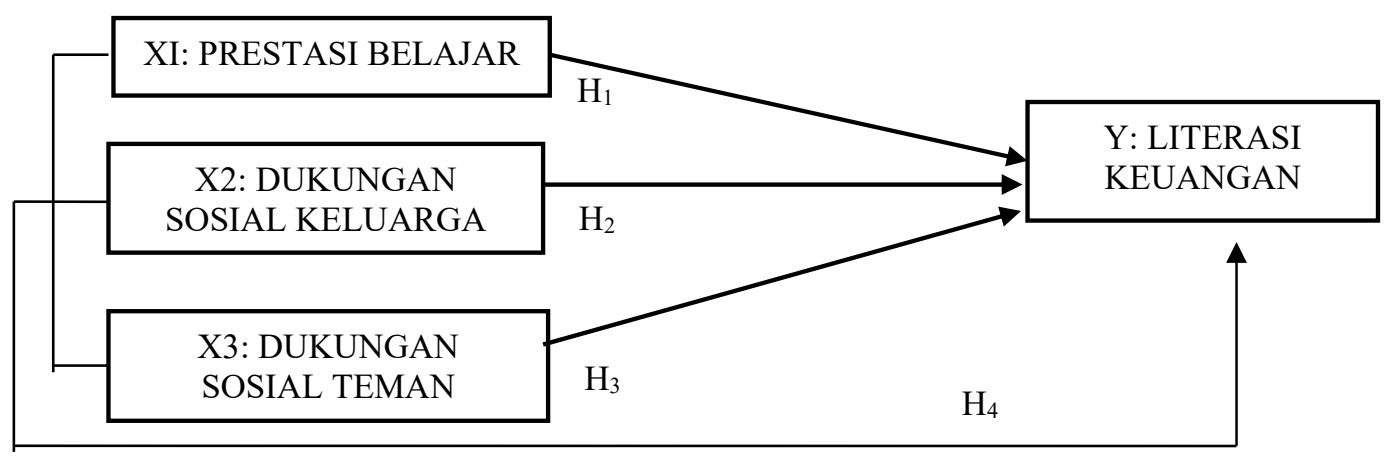

Gambar 1. Desain Penelitian

Populasi dalam penelitian ini adalah siswa-siswi kelas XII Program Studi IPS di SMA Negeri di Kabupaten Dompu, Provinsi Nusa Tenggara Barat yang tersebar di delapan kecamatan yaitu sebanyak 1083 siswa. Masing-masing sekolah memiliki hak serta kesempatan yang sama untuk dipilih menjadi sampel, maka penentuan sampel menggunakan teknik proporsional area probability sampling (Arikunto, 2010) yaitu dengan mengambil wakil dari setiap SMA Negeri yang ada di setiap kecamatan kemudian diambil sampel secara seimbang atau sebanding dengan jumlah siswa kelas XII Program Studi IPS di masing-masing sekolah, yaitu sebanyak 292 responden.

Penelitian ini menggunakan sumber data primer dari angket yang diberikan kepada responden tentang variabel dukungan sosial keluarga (X2), dukungan 
sosial teman sebaya (X3) dan literasi keuangan (Y) serta data sekuder berupa nilai ulangan akhir semester (UAS) genap dari guru mata pelajaran Ekonomi yang digunakan sebagai alat ukur variabel prestasi belajar (X1).

Penelitian ini menggunakan analisis regresi linear berganda, yaitu untuk mengetahui pengaruh tiga variabel bebas, yaitu prestasi belajar (X1), dukungan sosial keluarga (X2), dukungan sosial teman sebaya (X3) terhadap satu variabel terikat yaitu literasi keuangan $(\mathrm{Y})$. Persamaan yang digunakan adalah (Arikunto, 2010): $Y=\alpha+\beta_{1} X_{1}+\beta_{2} X_{2}+\beta_{3} X_{3}+$ ei.

\section{HASIL PENELITIAN DAN PEMBAHASAN}

Hasil penelitian pada variabel prestasi belajar siswa kelas XII SMA Negeri di Kabupaten Dompu, Provinsi Nusa Tenggara Barat menunjukkan bahwa nilai tertinggi sebesar 38,01\%, yaitu sebanyak 111 siswa memperoleh nilai ujian akhir semester (UAS) genap tahun ajaran 2014/2015 pada interval 78 - 72 dengan kriteria tinggi. Kemudian sebanyak $22,26 \%$, yaitu 65 siswa memperoleh nilai pada interval $71-65$ dengan kriteria sedang. Persentase pada urutan ketiga sebanyak $20,89 \%$, yaitu 61 siswa mencapai nilai pada interval 85 - 79 dengan kriteria sangat tinggi. Sedangkan persentase terendah, yaitu 18,84\%, sebanyak 55 siswa memperoleh nilai pada interval $64-58$ dengan kriteria rendah. Hal ini berarti bahwa sebanyak 172 responden atau 59\% dari 292 responden mencapai KKM dengan klasifikasi sangat tinggi dan tinggi.

Secara umum mean semua indikator pada variabel dukungan sosial keluarga dan teman sebaya dikategorikan tinggi dalam membentuk literasi keuangan siswa. Hal ini ditunjukkan dari mean jawaban responden pada angket dukungan sosial keluarga dan teman sebaya yang berada di interval 5.00 - 3.66 dengan kategori tinggi. Pada dukungan sosial keluarga khususnya indikator tangible support, di mana orang tua memberikan bantuan fisik kepada anak berupa pemberian uang saku untuk kebutuhan sekolah dan di luar sekolah, maupun tambahan uang saku jika ada pengeluaran lebih yang sangat baik bagi anak karena diperhatikan oleh orang tuanya sehingga anak bisa lebih berkonsentrasi dalam bersekolah. Pada dukungan sosial teman sebaya khususnya indikator expresi kasih sayang dan kepedulian (emotional support) responden memiliki teman sebaya yang mengajaknya untuk mengelola keuangan pribadinya dengan baik dan memberikan nasihat untuk rajin menabung. Dalam hal ini responden berada dalam pergaulan yang teman-teman sebayanya sadar untuk hidup hemat.

Secara umum mean semua indikator pada variabel literasi keuangan dikategorikan tinggi. Hal ini berarti bahwa siswa SMA Negeri di Kabupaten Dompu rata-rata memiliki literasi keuangan yang baik khususnya pada indikator memahami produk-produk keuangan yaitu memiliki rekening tabungan di bank, memahami pentingnya memiliki asuransi pendidikan dan kesehatan serta prosedur jual beli saham atau obligasi di bursa efek. Hal menunjukkan bahwa dari pembelajaran Ekonomi di sekolah membentuk pemahaman responden tentang produk-produk keuangan.

Berdasarkan uji signifikansi yang telah dilakukan maka model persamaan regresi dapat ditulis dalam bentuk persamaan regresi linier berganda sebagai berikut: $\mathrm{Y}=47.694+0.129 \mathrm{X}_{1}+0.209 \mathrm{X}_{2}+0.205 \mathrm{X}_{3}+$ ei. Hasil persamaan analisis regresi linier berganda di atas dapat diinterpretasikan sebagai berikut: 
1) Nilai konstanta (a) sebesar 47.694 artinya jika nilai variabel prestasi belajar, variabel dukungan sosial keluarga, dan dukungan sosial teman sebaya adalah nol, maka variabel literasi keuangan sama dengan 47.694. 2) Koefisien regresi variabel prestasi belajar $\left(\mathrm{X}_{1}\right)$ sebesar 0.129 , artinya setiap perubahan variabel prestasi belajar akan berpengaruh positif terhadap literasi keuangan sebesar 0.129 dengan asumsi variabel dukungan sosial keluarga dan teman sebaya tidak mengalami perubahan atau konstan. Nilai koefisien regresi positif menunjukkan pengaruh yang searah, artinya jika variabel prestasi belajar naik $1 \%$, maka akan berpengaruh pada kenaikan variabel literasi keuangan sebesar $0.129 \%$ dan sebaliknya. 3) Koefisien regresi variabel dukungan sosial keluarga $\left(\mathrm{X}_{2}\right)$ sebesar 0.209 , artinya setiap perubahan variabel dukungan sosial keluarga akan berpengaruh positif terhadap literasi keuangan sebesar 0.209 dengan asumsi variabel prestasi belajar dan teman sebaya tidak mengalami perubahan atau konstan. Nilai koefisien regresi positif menunjukkan pengaruh yang searah, artinya jika variabel dukungan sosial keluarga naik 1\%, maka akan berpengaruh pada kenaikan variabel literasi keuangan sebesar $0.209 \%$ dan sebaliknya. 4) Koefisien regresi variabel dukungan sosial teman sebaya $\left(X_{3}\right)$ sebesar 0.205 , artinya setiap perubahan variabel dukungan sosial teman sebaya akan berpengaruh positif terhadap literasi keuangan sebesar 0.205 dengan asumsi variabel prestasi belajar dan dukungan sosial keluarga tidak mengalami perubahan atau konstan. Nilai koefisien regresi positif menunjukkan pengaruh yang searah, artinya jika variabel dukungan sosial teman sebaya naik $1 \%$ maka akan berpengaruh pada kenaikan variabel literasi keuangan sebesar $0.205 \%$ dan sebaliknya.

Berdasarkan uji hipotesis pertama, diperoleh hasil uji-t bahwa prestasi belajar mata pelajaran Ekonomi memiliki nilai signifikansi $0.035<0.05$. Dimana prestasi belajar berpengaruh positif terhadap literasi keuangan siswa, sehingga dapat didiskripsikan bahwa semakin baik prestasi belajar maka semakin baik pula literasi keuangan siswa.

Hasil penelitian ini didasarkan pada pengertian prestasi belajar yang diungkapkan oleh para ahli, seperti Tu'u (2004) yang mendefinisikan prestasi belajar sebagai hasil dari penguasaan pengetahuan atau keterampilan setelah mengerjakan tugas atau kegiatan tertentu yang dikembangkan oleh mata pelajaran. Syah (2001) mendefinisikan prestasi belajar sebagai hasil yang dicapai siswa setelah melakukan interaksi dengan faktor-faktor yang mempengaruhi proses belajar. Djamarah (2002) mengemukakan bahwa prestasi belajar adalah perubahan dalam diri individu sebagai hasil dari aktivitas dalam suatu proses kegiatan belajar. Sehingga dapat disimpulkan bahwa prestasi belajar merupakan hasil belajar berupa pengetahuan dan keterampilan yang dicapai melalui serangkaian proses belajar dan tugas-tugas yang harus dikerjakan siswa sebagai bagian dari proses belajar.

Dalam penelitian ini menemukan bahwa sebanyak 172 responden atau 59\% dari 292 responden mencapai KKM dengan klasifikasi sangat tinggi dan tinggi, yaitu pada interval 78-72 dan 85-79. Prestasi belajar ini berpengaruh secara positif terhadap literasi keuangan siswa khususnya pada indikator money basic, yaitu responden mampu menghitung uang sakunya sendiri untuk dialokasikan pada pengeluaran rutinnya dan responden mampu menolak ajakan temannya untuk jalan-jalan jika tidak memiliki uang saku lebih. Hal ini menunjukkan bahwa responden memiliki kemampuan dasar dalam mengelola keuangan pribadinya 
yang diperoleh dari belajar mata pelajaran Ekonomi. Pengetahuan dasar siswa tentang keuangan yang mereka peroleh dari belajar Ekonomi yang ditunjukkan dengan prestasi belajar yang baik, telah membentuk literasi keuangan yang baik pula. Hal ini ditunjukkan dengan nilai signifikansi positif yang didukung oleh teori dan empiris.

Temuan dalam penelitian ini didukung oleh penelitian-penelitian sebelumnya yang dilakukan oleh Krishna (2010) yang menemukan bahwa mahasiswa yang berasal dari program studi Ekonomi, di mana mereka yang telah mempelajari mata kuliah yang berkaitan dengan pengelolaan keuangan dan mencapai prestasi belajar tentang keuangan, memiliki literasi keuangan lebih tinggi daripada mahasiswa yang berasal dari program studi non Ekonomi. Nababan (2011) dalam penelitiannya menemukan bahwa mahasiswa yang berasal dari program studi Ekonomi Pembangunan memiliki literasi keuangan lebih tinggi daripada mahasiswa program studi Manajemen. Dalam penelitiannya, Gutter et al. (2008) menyimpulkan bahwa baik pembelajaran sosial dan pendidikan formal merupakan penentu penting dari perilaku keuangan seseorang. Pendidikan dan pengetahuan keuangan merupakan faktor penting dalam membentuk perilaku keuangan seseorang.

Berdasarkan uji hipotesis kedua, diperoleh hasil uji-t bahwa dukungan sosial keluarga memiliki nilai signifikansi $0.01<0.05$, yang artinya dukungan sosial keluarga berpengaruh positif terhadap literasi keuangan siswa. Hasil penelitian ini didukung pendapat dari Albrecht dan Adelman (dalam Mattson, 2011) yang mendefinisikan dukungan sosial sebagai suatu bentuk komunikasi yang dapat membantu seseorang merasa lebih nyaman dan dapat mengatasi ketidakpastian suatu kondisi yang dihadapinya. Dukungan dari keluarga diberikan kepada anaknya agar dapat menghadapi tugas-tugas dalam proses belajar sehingga mereka merasa nyaman karena memiliki keluarga yang bisa mereka andalkan dalam kondisi sulit yang mungkin saja mereka temui.

Temuan penelitian ini didukung oleh penelitian Susanti (2013) yang menyimpulkan bahwa beberapa faktor yang mempengaruhi literasi keuangan mahasiswa Fakultas Ekonomi Universitas Negeri Surabaya diantaranya adalah pengaruh pembelajaran keuangan di keluarga dan perguruan tinggi. Penelitian Jorgensen (2007) menemukan hasil bahwa mahasiswa yang belajar pengelolaan keuangan pada orang tuanya memiliki pengetahuan keuangan yang lebih tinggi. Pembelajaran keuangan di keluarga dalam penelitian ini termasuk dalam dukungan sosial keluarga yang diberikan kepada anak dalam bentuk informasi tentang keuangan (information support). Cude et al. (2006) dalam penelitiannya juga menyimpulkan bahwa orang tua memegang peranan penting dalam proses sosialisasi keuangan kepada anak-anaknya. Agarwalla et al. (2013) dalam penelitiannya menemukan bahwa keterlibatan keluarga dalam memberikan bimbingan pada proses pengambilan keputusan tentang keuangan merupakan salah satu faktor yang mempengaruhi literasi keuangan pada pekerja muda. Clarke et al. (dalam Jorgensen, 2007) menyatakan bahwa pengaruh orang tua secara praktis seperti modeling dan teaching lebih kuat mempengaruhi literasi keuangan anak daripada pengaruh teman sebaya. Senada dengan Clarke et al., penelitian Jorgensen (2007) juga menemukan hasil bahwa pengaruh orang tua lebih kuat, sedangkan teman sebaya tidak memberikan pengaruh terhadap literasi keuangan. 
Pada Penelitian Jorgensen (2010) yang lain, menyatakan bahwa orang tua dan pendidik memiliki peran penting dalam meningkatkan literasi keuangan remaja.

Siswa SMA Negeri di Kabupaten Dompu mendapatkan dukungan sosial keluarga yang tinggi. Hal ini tentu saja berpengaruh positif terhadap literasi keuangan siswa, karena pengetahuan ekonomi dan keuangan yang telah mereka pelajari di sekolah ditindaklanjuti oleh keluarga di rumah melalui pembiasaan, penerapan dan contoh teladan yang diberikan orang tua kepada anak-anaknya tentang literasi keuangan.

Berdasarkan uji hipotesis ketiga, diperoleh hasil uji-t bahwa dukungan sosial teman sebaya memiliki nilai signifikansi $0.039<0.05$, yang artinya dukungan sosial teman sebaya berpengaruh positif terhadap literasi keuangan siswa. Hasil penelitian ini didukung oleh teori-teori tentang dukungan sosial yang dapat dikatakan sebagai bagian dari proses interaksi seorang anak dengan lingkungannya. Dalam Teori Ekologis yang dikemukakan Bronfenbrenner (dalam Santrock, 2003) menyatakan bahwa anak dalam perkembangannya berinteraksi dengan lingkungan di mana mereka tinggal yang mencakup orang tua dan teman sebayanya. Vaux (dalam Azizi, 2013) juga berpendapat bahwa masing-masing orang memiliki jaringan sosial yang luas yang terbentuk dari beberapa jaringan sosial yang lebih kecil, yaitu keluarga dan teman sebaya, untuk mendukungnya dalam menghadapi tuntutan-tuntutan dalam kehidupannya dan mencapai tujuan hidupnya. Teman sebaya sebagai bagian dari mikrosistem seorang anak dapat memberikan pengaruh positif maupun negatif, termasuk dalam membentuk literasi keuangan seorang anak karena pola pergaulan di antara mereka. Anna Freud (dalam Santrock, 2003) yang menyatakan bahwa remaja memiliki kecenderungan untuk mengalihkan perasaan mereka dari masa kanak-kanaknya pada orang lain, sebagai pengganti orang tua, yaitu teman sebaya, di mana teman sebaya berfungsi sebagai salah satu sumber informasi tentang banyak hal yang diperoleh remaja di luar keluarganya.

Temuan pada penelitian ini didukung penelitian Susanti (2013) yaitu salah satu faktor yang mempengaruhi literasi keuangan mahasiswa Fakultas Ekonomi Universitas Negeri Surabaya adalah pengaruh interaksi dengan teman sebaya. Lusardi et al. (2010) dalam penelitiannya menyatakan bahwa teman sebaya memiliki peran dalam menjelaskan perbedaan literasi keuangan. Brown et al. (dalam Lusardi et al., 2010) juga menyatakan bahwa teman sebaya merupakan salah satu pihak yang berkontribusi dalam memberikan informasi dan nasehat keuangan. Siswa SMA Negeri di Kabupaten Dompu secara umum mendapatkan dukungan sosial teman sebaya yang tinggi. Hal ini tentu saja berpengaruh positif terhadap literasi keuangan siswa, karena pengetahuan ekonomi dan keuangan yang telah mereka pelajari di sekolah dapat diterapkan dalam kehidupan seharihari melalui pergaulan yang baik dan positif dengan teman sebayanya, sehingga siswa memiliki literasi keuangan yang baik pula.

Berdasarkan uji hipotesis keempat, diperoleh hasil uji-f bahwa prestasi belajar, dukungan sosial keluarga dan teman sebaya secara simultan berpengaruh positif terhadap literasi keuangan siswa dengan nilai signifikansi $0.001<0.05$. Nilai koefisien determinasi $\left(\mathrm{R}^{2}\right)$ diketahui bahwa nilai R-square adalah 0.054 . Hal ini menunjukkan bahwa literasi keuangan siswa SMA Negeri di Kabupaten Dompu dipengaruhi oleh prestasi belajar, dukungan sosial keluarga dan teman 
sebaya sebesar 5,4\%, sedangkan 94,6\% dipengaruhi oleh variabel-variabel lain di luar variabel yang diteliti.

Pada penelitian ini menemukan bahwa siswa memiliki prestasi belajar yang baik dengan nilai mata pelajaran Ekonomi di atas kriteria ketuntasan mengajar (KKM) dan secara umum siswa mendapatkan dukungan sosial keluarga dan teman sebaya yang tinggi sehingga literasi keuangan siswa juga baik. Hal ini didukung oleh penelitian Susanti (2013) yang menemukan bahwa beberapa faktor yang mempengaruhi literasi keuangan mahasiswa Fakultas Ekonomi Universitas Negeri Surabaya adalah pengaruh pembelajaran keuangan di keluarga dan perguruan tinggi serta pengaruh interaksi teman sebaya. Penelitian Jorgensen (2007) menemukan hasil bahwa mahasiswa yang belajar tentang pengelolaan keuangan pada orang tuanya memiliki pengetahuan keuangan yang lebih tinggi daripada yang tidak. Cude et al. (2006) dalam penelitiannya juga menyimpulkan bahwa orang tua memegang peranan penting dalam proses sosialisasi keuangan kepada anak-anaknya. Penelitian Lusardi et al. (2010) menemukan bahwa kemampuan kognitif yang diperoleh sebagai hasil belajar, karakteristik keluarga dan teman sebaya memiliki peran dalam menjelaskan perbedaan literasi keuangan.

Siswa SMA Negeri di Kabupaten Dompu dengan prestasi belajar yang baik dan mendapatkan dukungan sosial keluarga serta teman sebaya yang tinggi dapat mencapai literasi keuangan yang baik pula. Maka dalam penelitian ini ditemukan bahwa prestasi belajar, dukungan sosial keluarga dan teman sebaya merupakan faktor-faktor yang mempengaruhi literasi keuangan siswa SMA Negeri di Kabupaten Dompu.

\section{SIMPULAN}

Berdasarkan hasil penelitian, dapat disimpulkan bahwa: 1) Prestasi belajar mata pelajaran Ekonomi berpengaruh positif terhadap literasi keuangan siswa SMA Negeri di Kabupaten Dompu, yang berarti bahwa semakin baik prestasi belajar maka semakin baik pula literasi keuangan siswa, 2) Dukungan sosial keluarga berpengaruh positif terhadap literasi keuangan siswa SMA Negeri di Kabupaten Dompu, yang berarti bahwa semakin baik dukungan sosial keluarga yang diberikan kepada anak maka semakin baik pula literasi keuangannya, 3) Dukungan sosial teman sebaya pengaruh positif terhadap literasi keuangan siswa SMA Negeri di Kabupaten Dompu, yang berarti bahwa semakin baik dukungan sosial yang diperoleh siswa dari teman sebayanya maka semakin baik pula literasi keuangannya, 4) Prestasi belajar, dukungan sosial keluarga dan teman sebaya secara simultan pengaruh terhadap literasi keuangan siswa SMA Negeri di Kabupaten Dompu sehingga dapat dikatakan bahwa ketiga variabel tersebut merupakan faktor-faktor yang mempengaruhi literasi keuangan siswa SMA Negeri di Kabupaten Dompu.

Berdasarkan simpulan penelitian, maka disarankan: 1) Prestasi belajar yang baik dapat dicapai melalui proses belajar yang baik pula, sehingga kompetensikompetensi dasar ekonomi dan keuangan yang dipelajari siswa dapat dikuasai dan bermakna. Maka dari itu disarankan kepada sekolah khususnya guru bidang studi Ekonomi untuk dapat menciptakan proses belajar yang baik di kelas. Sekolah menfasilitasinya dengan sarana yang memadai, misalnya mengembangkan koperasi siswa yang dikelola langsung oleh siswa sebagai laboratorium mata 
pelajaran Ekonomi. Siswa di kelas juga dilibatkan untuk mengelola keuangan kelasnya sendiri seperti uang kas dan tabungan harian sehingga proses belajar dapat berlangsung secara berkelanjutan melalui program sekolah. Hal ini diarahkan agar siswa memiliki literasi keuangan. 2) Keluarga khususnya orang tua hendaknya menyadari bahwa tanggung jawab dan kewajiban membentuk literasi keuangan anak bukan semata-mata dibebankan pada guru melalui proses belajar mata pelajaran Ekonomi yang berlangsung di sekolah. Orang tua seharusnya tidak hanya puas menerima prestasi belajar Ekonomi anak berupa nilai yang di atas kriteria ketuntasan minimal (KKM), tapi juga memberikan dukungan berupa bimbingan, pembiasaan dan contoh tentang penerapan literasi keuangan sehingga pengetahuan dasar keuangan yang mereka peroleh dari sekolah dapat lebih bermanfaat sebagai penerapan literasi keuangan dalam kehidupan sehari-hari. Hal ini dapat dilakukan dari hal yang paling sederhana misalnya melibatkan anak dalam belanja rutin kebutuhan keluarga, mengajak anak untuk mengumpulkan uang sedikit demi sedikit apabila ada barang yang ingin dibeli dan memberikan kepercayaan kepada anak untuk mengelola uang saku yang diberikan mingguan ataupun bulanan sehingga anak terbiasa untuk mengatur pengeluaran rutinnya. 3) Semua pihak dan komponen yang terlibat dalam proses belajar anak, termasuk teman sebaya mereka, hendaknya dapat memperhatikan pola pergaulan dan interaksi di antara mereka sehingga terjadi pola pergaulan yang positif khususnya yang mengarah pada literasi keuangan. Hal ini juga tidak terlepas dari pengawasan orang tua dan sekolah sebagai bentuk dukungan sosial yang diberikan kepada anak.

\section{DAFTAR RUJUKAN}

Agarwalla, S.K., Barua, S.K., Jacob, J., \& Varma, J.R, 2013. Financial Literacy among Working Young in Urban India. Indiana Institute of Management Ahmedabad.

Arikunto, S, 2010. Prosedur Penelitian suatu Pendekatan Praktek. Jakarta: Rineka Cipta.

Azizi, Y, 2013. The Study of The Relationship among Emotional Intelligence, Peer Social Support, and Family Social Support and GPA among Iranian High School Students. European Online Journal of Natural and Social Science, 2.

Capuano, A., \& Ramsay, I, 2011. What Causes Suboptimal Financial Behaviour? An Exploration of Financial Literacy, Social Influences and Behaviour Economics. Social Science Research Network Electronic Library (540). Australia: The University of Melbourne.

Cude, B.J., Lawrence, F.C., Lyson, A.C., Metzger, K., LeJeune, E., Marks, L., \& Machtmes, K, 2006. Collage Student and Financial Literacy: What They Know and What We Need to Learn. Eastern Family Economic and Resource Management Association.

Djamarah, S.B., \& Zain, A, 2002. Strategi Belajar Mengajar. Jakarta: PT. Rineka Cipta.

Fezer, M, 2008. Adolescent Social Support Network Student Academic Success as it Relates to Source and Type of Support Received. Dissertation. New York: State University of New York at Buffalo. 
Gutter, M.S., \& Garrison, S, 2009. Financial Management Practice of Collage Student from States with Varying Financial Education Mandates. National Endowment for Financial Education

Jorgensen, B.L., \& Savla, J., 2010. Financial Literacy of Young Adults: The Importance of Parental Socialization. ProQuest , 59, 465-478.

Krishna, R.A., \& Mayasari, 2010. Analisis Tingkat Literasi Keuangan di Kalangan Mahasiswa dan Faktor-faktor yang Mempengruhinya. Joint Conference UPI \& UPSI. Bandung.

Littlewood, K., Swanke, J.R., Strozier, A., \& Kondrat, D, 2012. Measuring Social Support among Kinship Caregivers: Validity and Reliability of The Family Support Scale. Child Welfare , 91.

Lusardi, A., Mitchelle, O.S., \& Curto, V, 2010. Financial Literacy among The Young: Evidence and Implications for Consumer Policy. National Bureau of Economics Research , 44 (2).

Mashlihah, S, 2011. Study tentang Hubungan Dukungan Sosial, Penyesuaian Sosial di Lingkungan Sekolah dan Prestasi Akademik Siswa Asyfa Boarding School Subang Jawa Barat. Jurnal Psikologi Undip , 10 (2).

Mattson, 2011. Linking Health Communication with Social Support. p. 182.

Nababan, D., \& Sadalia, I, 2011. Analisis Personal Financial Literacy dan Financial Behavior Mahasiswa Strata 1 Fakultas Ekonomi Universitas Sumatera Utara.

Remund, D. L, 2010. Financial Literacy Explicated: Tnomyhe Case for a Clearer Definition in an Increasingly Complex Ec. Journal of Consumer Affairs, $44(2)$.

Santrock, J. W, 2003. Andolescence (6th edition ed.). Terjemahan oleh W. C. Kristiaji., Y. Sumiharti, Eds., S. B. Adelar., \& S. Saragih, Trans. Penerbit: Erlangga.

Safree, M.A., \& Adawiah, M, 2011. The Relationship between Social Support and Academic Achievement. International Journal of Humanities and Social Science, 1(5), 277-281.

Susanti, 2013. Faktor-faktor yang Mempengaruhi Literasi Keuangan Mahasiswa Fakultas Ekonomi Universitas Negeri Surabaya. Jurnal danBisnis Vol. 18 Universitas Negeri Malang.

Syah, M, 2001. Psikologi Belajar. Jakarta: Bumi Aksara.

Tu'u, T, 2004. Peran Disiplin pada Perilaku dan Prestasi Siswa. Jakarta: Grasindo. 